\title{
How do seaweed farms influence local fishery catches in a seagrass-dominated setting in Chwaka Bay, Zanzibar?
}

\author{
Johan S. Eklöf ${ }^{a}$, Maricela de la Torre-Castro ${ }^{2}$, Camilla Nilsson ${ }^{3}$ and Patrik Rönnbäck \\ Department of Systems Ecology, Stockholm University, S-106 91 Stockholm, Sweden
}

Received 5 October 2005; Accepted 7 April 2006

\begin{abstract}
Seaweed farming is often depicted as a sustainable form of aquaculture, contributing to poverty reduction and financial revenues in producer countries. However, farms may negatively affect seagrasses and associated organisms (e.g. invertebrate macrofauna) with possible effects on the flow of ecosystem goods and services to coastal societies. The present study investigates the influence of a seaweed farm, and the farmed seaweed Eucheuma denticulatum in particular, on fishery catches using a traditional fishing method ("madema" basket traps) in Chwaka bay (Zanzibar, Tanzania). The results suggest that a seaweed farm, compared to a seagrass bed, had no influence on catch per unit effort (no. of individuals per catch, or catch weight) or no. of species per catch, but significantly affected catch composition (i.e. how much that was caught of which species). The two species contributing most to differences between the sites were two economically important species; the herbivorous seagrass rabbit fish Siganus sutor, which was more common in the seaweed site and is known to graze on the farmed algae; and the benthic invertebrate feeder chloral wrasse Cheilinus chlorourus, more common in the seagrass site. Compared to vegetation-free bottoms, however, the catches were 3-7 times higher, and consisted of a different set of species (ANOSIM global $R>0.4$ ). As traps placed close to the seaweeds fished three times more fish than traps placed on sand patches within the seaweed farm, the overall pattern is attributed to the presence of submerged vegetation, whether seagrass or seaweed, probably as shelter and/or food for fish. However, qualitative differences in terms of spatial and temporal dynamics between seagrass beds with and without seaweed farms, in combination with other factors such as institutional arrangements, indicate that seaweed farms cannot substitute seagrass beds as fishing grounds.
\end{abstract}

Key words: Artisanal fisheries / Fish trap catches / Seaweed farming / Aquaculture / Rhodophyta / Meadows / Seagrass loss / Indian Ocean

Résumé - Comment les fermes aquacoles d'algues influencent-elles les captures locales de poissons, dans une zone de prairies marines, de la baie de Chwaka, Zanzibar? Les cultures d'algues sont souvent dépeintes comme une forme d'aquaculture durable, contribuant à la réduction de la pauvreté, et sources de revenus pour les pays producteurs. Cependant, des fermes peuvent influencer négativement les herbiers marins et les organismes associés (ex. la macrofaune d'invertébrés) avec de possibles effets sur fonctionnement de l'écosystème, et sur leur service aux sociétés côtières. Cette étude porte sur l'influence d'une ferme aquacole d'algues, Eucheuma denticulatum en particulier, sur les captures de pêche utilisant un mode traditionnel de capture (nasses appelées «madema ») dans la baie de Chwaka (Zanzibar, Tanzanie). Les résultats montrent qu'une ferme aquacole, comparée à une zone d'herbier, n'a pas d'influence sur les captures par unité d'effort (nombre d'individus par capture or poids des captures) ou le nombre d'espèces par capture, mais affectent significativement la composition des captures (par espèce). Les deux espèces contribuant aux différences entre sites sont importantes économiquement; un herbivore, le poisson-lièvre, Siganus sutor, qui est plus commun dans l'herbier mais connu pour se nourrir des algues cultivées; et le poisson labre Cheilinus chlorourus, commun dans l'herbier, et qui se nourrit d'invertébrés benthiques. Cependant, comparées à des fonds dépourvus de végétation, les captures sont 3 à 7 fois plus élevées, et consistent en différentes associations d'espèces (ANOSIM $R>0,4)$. Lorsque les nasses sont placées à proximité des algues, elles pêchent 3 fois plus de poissons que celles placées sur les zones de sable situées dans la zone aquacole; la tendance est attribuée à la présence de végétation submergée, herbes marines ou algues, probablement en tant qu'abri ou nourriture pour ces poissons. Cependant, les différences qualitatives en termes dynamiques spatiales et temporelles entre les herbiers avec ou sans fermes aquacoles, en combinaison avec d'autres facteurs tels que des arrangements institutionnels, indiquent que les fermes de culture d'algues ne peuvent se substituer à des herbiers en tant que zones de fonds de pêche.

a Corresponding author: johane@ecology.su.se 


\section{Introduction}

Seaweed farming, i.e. mariculture of macroalgae, is often depicted as a sustainable form of aquaculture, and has significantly contributed to poverty reduction and financial revenues to producers like Zanzibar (Tanzania) in the Western Indian Ocean (Petterson-Lofquist 1995; Ronnback et al. 2002). However, a growing body of evidence suggests that the activity affects benthic communities both underneath and outside farms (for review see Zemke-White 2003), which actualizes discussions on the actual degree of sustainability.

In many areas, e.g. particular coastal communities on Zanzibar, seaweed farms are often placed on seagrass beds, either because they are regarded to indicate suitable growing conditions or because non-vegetated sites are not present (de la Torre-Castro and Ronnback 2004). Seagrass beds in the Western Indian Ocean region generally host diverse and abundant fish communities (e.g. Pollard 1984; Gell and Whittington 2002; Gullstrom et al. 2002, 2006), and are therefore considered important fishing grounds, especially in artisanal fisheries (Gell 1999; de la Torre-Castro and Ronnback 2004).

Recent studies suggest that the presence of seaweed farms reduces seagrass biomass and growth rates (Semesi 2002; Eklöf et al. 2005; Eklöf et al. in press), and seaweed farmers frequently remove seagrass shoots of large species (de la Torre-Castro and Ronnback 2004). The effects also seem to be transferred to higher trophic levels, e.g. macroscopic infauna (Eklöf et al. 2005), larger invertebrate epifauna (Eklöf et al. in press) and fish communities (Bergman et al. 2001), despite fish being non-stationary and migrating with the tides. However, as the farmed algae provide structural complexity i.e. the arrangement and diversity of elements in space (Bergman et al. 2001), and provide a direct food source to some herbivores (Neish 2003), anecdotes suggest that seaweed farms can potentially increase fishery catches of some species in settings where natural submerged vegetation is scarce (Mtolera et al. 1992).

In light of this, we investigated how seaweed farms influenced fishery catches in a seagrass-dominated setting. Using traditional "madema" basket fish traps, fish catches were compared i) between a seaweed farm, seagrass bed and unvegetated sand bank, and ii) between microhabitats (farmed algae or bare sand) within a seaweed farm. The results are discussed in relation to the importance of farmed seaweeds and how to increase the overall sustainability in the use of these resources.

\section{Materials and methods}

\subsection{Study area}

The study was performed in Chwaka Bay (Zanzibar, Tanzania) (Fig. 1), a $50 \mathrm{~km}^{2}$ shallow water body dominated by inter- and subtidal banks vegetated by both mixed and monospecific stands of seagrasses (about 10 species) and benthic macroalgae (e.g. Cederlof et al. 1995; Muzuka et al. 2001; de la Torre-Castro and Ronnback 2004; Kangwe 2006). The area has a strong and asymmetric semidiurnal tidal regime,

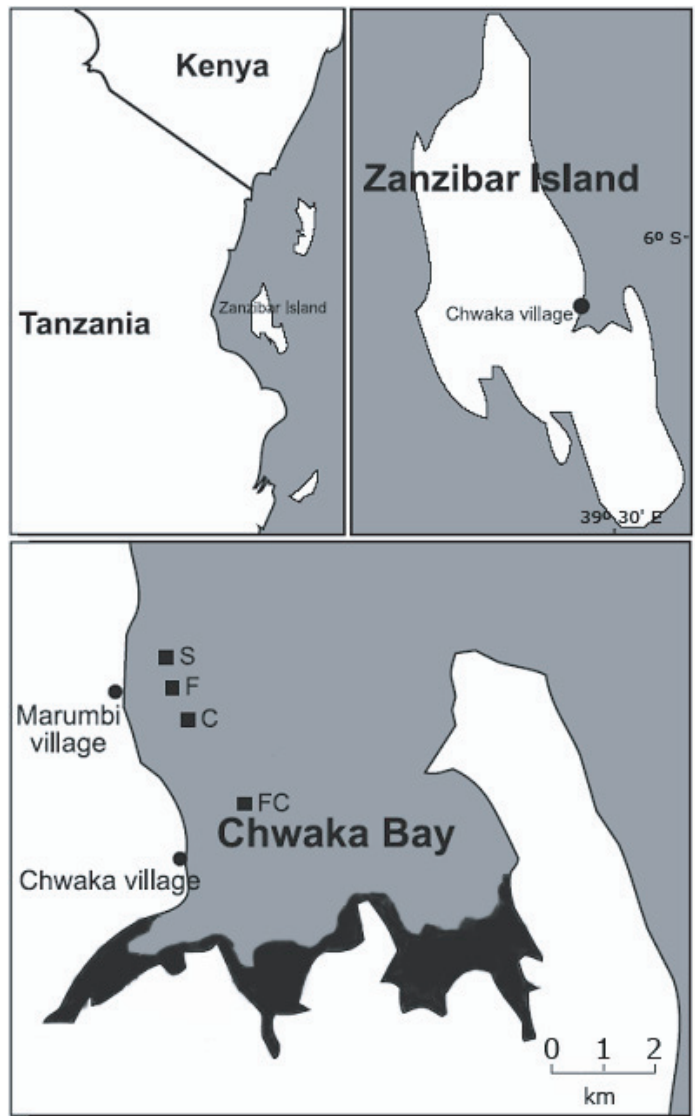

Fig. 1. Map over East Africa (upper left); Zanzibar (upper right), and the study area Chwaka Bay (below), with the positions of the sampling sites. F: seaweed farm, C: seagrass bed, S: sand bank, FC: seaweed farm. Black areas represent dense mangroves.

and the tidal range is $0.9 \mathrm{~m}$ during neap tides and $3.2 \mathrm{~m}$ during spring tides (Cederlöf et al. 1995). Salinity in the sampling area was previously recorded to $25.5 \mathrm{psu}$ (ranging from 21 to 28) (Eklöf et al. 2005).

Open-water seaweed farming is, second to artisanal nearshore fisheries, the most important livelihood option in the bay (de la Torre-Castro and Ronnback 2004), and was introduced around 1990. Currently, two species of red algae - Eucheuma denticulatum and Kappaphycus alvarezii - are farmed using the "off-bottom" method, where algal fronds are tied to lines stretched between wooden sticks driven into the bottom, and harvested every 2-3 months. The farms are placed in intertidal areas with adequate environmental conditions (e.g. clear water, adequate currents, and proper substrate), and as in many other areas, many of these sites are initially covered with seagrasses and/or benthic macroalgae. This is partly supported by the fact that more than $50 \%$ of the seaweed farmers in Chwaka village report removal of seagrasses prior to the establishment of farms (de la Torre-Castro and Ronnback 2004).

Currently, most of the seaweed farms in the bay are located in close vicinity of the major villages, and cover about $2.5 \mathrm{~km}^{2}$ or $5 \%$ of the bay surface area (de la Torre-Castro and Ronnback 2004). 


\subsection{Trap fisheries}

The influence of seaweed farms on artisanal fish catches was investigated using madema basket traps, since investigations of fish communities using standard methods such as beam trawls or drag nets are impossible to use within seaweed farms due to the presence of the farmed seaweeds, sticks and lines. However, similar basket traps have been successfully used in studies on fish communities and fisheries in the Western Indian Ocean region before (e.g. McClanahan and Kaunda-Arara 1996; McClanahan and Mangi 2000; Kaunda-Arara and Rose 2004; McClanahan and Mangi 2004). The traps used in this study were hexagonal wooden traps (Bambusoideae or Maetenus spp.), measuring approximately $0.95 \times 1.10 \times 0.2 \mathrm{~m}$, with a mesh size of $3 \mathrm{~cm}$. They are normally placed in subtidal (and occasionally intertidal) areas in seagrass beds or among scleractinian corals, and the fish is lured into a narrowing funnel by the bait, usually comprised of benthic macroalgae, seagrass leaves, sea stars or brittle stars (Jiddawi and Ohman 2002). In the present study, a mixture of seagrass, benthic algae, brittle stars (Ophiuroidea) and an epiphytic sponge (Halichondria sp.; local name: "gozi") was used, since it is the preferred bait type in the area (de la Torre-Castro and Ronnback 2004). The bait was collected by two local fishermen the same day as the traps were set out.

During initial testing, local "madema" fishermen explained that the exact position of the traps (on a $<1 \mathrm{~m}$ scale), following available vegetation, was considered a highly important factor to achieve good catches; the traps are normally placed with the funnel towards seagrass patches of Enhalus acoroides or Thalassodendron ciliatum. To resemble the local fishing method, we therefore placed all traps in a similar nonrandom manner within the study sites, aided by a local fisherman. In the seaweed farm site the traps were placed either in seagrass patches remaining in the vicinity of the seaweeds, towards farmed algae, or in sand patches between farms plots (based on the suitability of the actual spot).

\section{Between-site comparison}

The study was conducted in April-June 2004, and investigated the influence of a seaweed farm on fish catches using a site-for-time comparison, since no historical fish catch data prior to the seaweed farm establishment was available. Three sites, all situated in approximately the same relative water depth (mean depth: $2.3 \mathrm{~m}$, ranging from 0.5 to $3.9 \mathrm{~m}$ ) and distance from the highest shoreline (Fig. 1), were included in the design; one seaweed farm situated on a old seagrass bed with Thalassia hemprichii and Enhalus acoroides (site F), one seagrass control site with Thalassia hemprichii and Enhalus acoroides (site $\mathrm{C}$ ), and one sand bank as a control for the presence of vegetation (site $S$ ).

All sampling was conducted during neap tides, since the sites were more or less exposed during low water spring tides. In the morning (10 $\mathrm{AM} \pm 60 \mathrm{~min}$ ) five fish traps, each with $1 \mathrm{dm}^{3}$ of bait, were placed approximately $20 \mathrm{~m}$. apart within each site, and the exact position of each trap was marked by a buoy. Approximately $24 \mathrm{~h}$ later, the traps were retrieved, emptied of all organisms, any remaining bait was removed and replaced by a fresh batch, and the traps were set out again in a new position. All fifteen traps were shifted randomly between the three sites each day, to prevent any differences between traps interfering with the site comparisons. The whole procedure was conducted for six days, during three neap tides, resulting in a total of 18 sampling days. In the analysis all days were pooled and treated as replicate samples, since the aim was to compare catches between sites including any temporal variation $(n=18)$.

To investigate whether certain site-specific habitat or environmental variables were important for fish catches, the relative cover of seagrasses (all species pooled), farmed algae, and benthic macroalgae was estimated within a $0.25 \mathrm{~m}^{2}$ frame in front of the trap funnel, and at two randomly selected places within five $\mathrm{m}$ from the trap (which were later averaged to form one replicate value). In addition, water temperature $\left({ }^{\circ} \mathrm{C}\right)$, the time the trap was in the water (min), tidal range (the difference between maximum and minimum water depth during the sampling, based on standard tide tables, $\mathrm{m}$ ) and weather conditions (cloud cover, \%) were noted.

After being brought to the lab, all organisms caught were weighed (wet weight, $g$ ), measured (Standard length; $S L$, in $\mathrm{mm}$ ) and identified to the lowest taxonomic level possible (usually species) using standard literature for the area (Bianchi 1985; Burgess et al. 2000; Lieske and Myers 2001; Smith and Heemstra 2003; Froese and Pauly 2004). All species were assigned to one of the following trophic groups; algal herbivores (HA), seagrass herbivores (HS), herbivores and planktivores $(\mathrm{H}, \mathrm{P})$, benthic invertebrate feeders $(\mathrm{BI})$, invertebrate feeders (I), invertebrate and fish feeders (IF), and omnivores (O) (following Bergman et al. 2001; Lieske and Myers 2001; Gell and Whittington 2002; Froese and Pauly 2005).

\section{Microhabitat comparisons}

A second study was performed in December 2004, comparing fish catches between microhabitats within a seaweed farm. The study was performed in the central part of the Chwaka village seaweed farm, situated on an intertidal bank between two tidal channels (site FC, Fig. 1). The mean vegetation cover (dominated by Thalassia hemprichii, Enhalus acoroides and Halimeda spp.) in the actual area within the farm used for sampling ( $5 \mathrm{ha}$ ) was $<5 \%$.

Five sampling sites, located $>20 \mathrm{~m}$ from the closest farm edge to avoid influence by the surrounding tidal channels, were randomly selected each day. Two traps were placed $>20 \mathrm{~m}$ apart in each site; one trap was set within a seaweed plot with the entrance close to $(0.1-0.2 \mathrm{~m})$ the farmed seaweeds, and another between farm plots on bare sand (here defined as $>95 \%$ cover of sand $>10 \mathrm{~m}$ from extensive vegetation cover). This resulted in one algal treatment (Algae), and one sand treatment as a control for the presence of algae (Sand). The same type and amount of bait mixture, collected by the same fishermen, was used in the traps. After $24 \mathrm{~h}$ the traps were collected and the catch was brought to the lab. All organisms were identified, weighed, measured and assigned to trophic groups, using the same protocol as in the between-site study (see above). This procedure was repeated for five consecutive days, with a 
new set of microhabitats within the study area sampled each day $(n=5)$. As described above, all traps were randomly relocated between the sites and treatments each day. Also the same substrate and environmental variables (percentage cover of seagrass, E. denticulatum, other macroalgae and sand [but here only in front of the trap funnel], water temperature, time in water, tidal range, and cloud cover) were noted.

\subsection{Data analysis}

\section{Univariate analyses}

All catch data were normalized as average daily catch per trap, since catches retrieved by local "madema" fishermen are normally composed of the pooled catches from a number of traps. The reason for not using the pooled daily catch from all five traps per site was that some traps were lost during sampling, and the catches during these days were based on less than five (four, and on one occasion three) traps. However, correlation analysis showed that the number of traps used per day did not influence either the number of individual organisms caught $\left(r^{2}=0.003 ; p=0.67\right)$, catch biomass $\left(r^{2}=0.01\right.$; $p=0.45)$, or the number of species $\left(r^{2}=0.018 ; p=0.32\right)$. Data were analysed both for fish alone and for fish and crabs combined, the main reason being that fish is the target group in madema fisheries, while crabs are only retrieved when accidentally caught.

Differences in no. of individuals per catch, catch weight, number of species, and mean fish size between sites, for fish and crabs combined, as well as for fish alone, were analysed using one-way ANOVA (between-site comparison) and Student's t-test (microhabitat comparison). Homogeneity of variances was tested using Cochran's C test or Levene's test. Significant ANOVA main effects were further analysed using the Tukey's HSD test. When assumptions could not be met, data were transformed using $\log (x+1)$ or $\log (x+10)$, or the non-parametric Kruskal Wallis Median test was used.

Significant main effects were then further tested using pairwise Mann-Whitney U tests, with the significance level adjusted according to the sequential Bonferroni method (Holm 1979). When not otherwise stated, significance levels were set at $\alpha=0.05$.

\section{Multivariate analyses}

Differences in catch composition (based on species or trophic groups) between the three sites were described using non-metrical multidimensional scaling ordination (MDS) (Clarke 1993), and were tested using one-way analysis of similarities (ANOSIM) randomization test (Clarke 1988). The species contributing most to dissimilarities between sites were identified using the similarity percentage (SIMPER) routine (Warwick et al. 1990). The role of six environmental variables (water temperature, tidal range, cloud cover (\%), and cover of seagrass (\%), macroalgae and Euchema denticulatum (\%) in front of the trap mouth) for catch composition was analysed using the BIO-ENV routine, based on the Spearman correlation coefficient $\rho$ (Clarke and Ainsworth 1993).

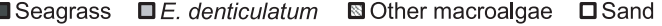

a) Substrate cover (\%) at trap funnel

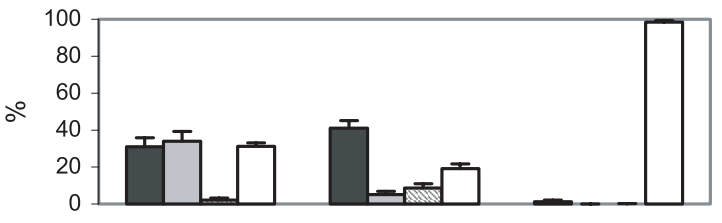

b) Substrate cover (\%) $5 \mathrm{~m}$ from trap

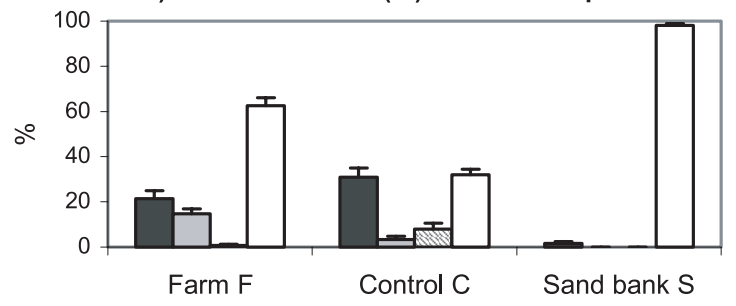

Fig. 2. Substrate cover (\% of seagrass, Eucheuma denticulatum, other macroalgae, and sand) at a) trap funnel, b) within $5 \mathrm{~m}$ of the trap $($ mean $\pm \mathrm{SE} ; n=18)$.

All analyses were run on 4th root-transformed catch weight data (separated per species or trophic group) and the Bray-Curtis coefficient of similarity (Clarke 1993), using the PRIMER software for Windows v. 5.2.9.

\section{Results}

\subsection{Comparisons of catches between sites}

\section{Generalities}

Over the whole study period, the water temperature was $28 \pm 0.4{ }^{\circ} \mathrm{C}$ (ranging from 26 to $31^{\circ} \mathrm{C}$ ), the tidal amplitude was $2.0 \pm 0.1 \mathrm{~m}$ (ranging from 1.1 to $2.9 \mathrm{~m}$ ), and relative cloud cover was $50 \pm 8 \%$ (ranging from 5 to $100 \%)($ mean $\pm 1 \mathrm{SE} ; n=18)$. The relative cover of major benthic substrate categories (seagrass, Eucheuma denticulatum, other macroalgae and sand) in front of the trap funnel and within a five $m$ radius of the traps are presented in Figs. $2 a$ and $2 b$. Noteworthy is the relatively high cover of seagrass in the seaweed farm $(\mathrm{F})$, both in front of the trap funnel and next to the trap (31 and $21 \%$, respectively), compared to that in the seagrass site (C) (41 and 31\%, respectively). This is explained by the non-random placement of the traps within the sites; in the farm $(\mathrm{F})$, traps were placed either with the funnel close to remnant seagrass patches (mostly the small Thalassia hemprichii) or the farmed seaweeds, whereas in the seagrass site traps were placed towards large and dense seagrass patches (often the large Enhalus acoroides). Using randomly collected benthic cover data, (not including cover of E. denticulatum), the seagrass cover within the seaweed farm was only $18 \%$ (Eklöf et al. 2005) i.e. 50\% lower than shown here.

Out of the 270 traps sampled during the study, eleven (4\%) were lost during sampling and 113 (43\% of the remaining) were empty on retrieval. There was no difference between the 
three sites in how many of the traps that were empty on a daily basis $\left(F_{2,17}=1.54 ; p=0.22\right)$. In the remaining 146 traps, a total of 448 fishes and 45 crabs, belonging to 17 families and 32 species (29 teleost fish and three crabs) were caught (Table 1).

Fifteen species were caught in the seagrass site (C), 21 species in the seaweed farm $(\mathrm{F})$, and nine species in the sand bank (S). Eight species were common to the seagrass (C) and the seaweed farm sites $(\mathrm{F})$, five species to the seaweed farm (F) and the sand bank (S), but no species were caught both in the seagrass site $(\mathrm{C})$ and the sand bank (S). Furthermore, no species were caught in all three sites.

The five species contributing most $(81 \%)$ to total biomass (all sites pooled) were seagrass rabbit fish Siganus sutor (23\%), bluebarred parrotfish Scarus ghobban (19\%), seagrass parrotfish Leptoscarus vaigiensis (14\%), blue crab Portunus pelagicus (14\%) and black-spot snapper Lutjanus fulviflamma (11\%). With exception of the scorpion fish Scorpaena scrofa, all species caught are of either subsistence or commercial value for local communities.

\section{Comparison of catch per unit effort}

In terms of no. of individuals per catch, there was an overall difference between the three sites, both in terms of fish and crabs combined (Kruskal Wallis; $p<0.001$ ) and fish alone (Kruskal Wallis; $p<0.001$ ) (Fig. 3a). There was no difference between the seaweed farm (F) and the seagrass bed (C), either in terms of fish and crabs together, or fish alone $(p>0.05$ for all comparisons), but traps placed in the sand bank (S) fished on average one third of the number of individual fish and crabs ( $p<0.001$ for F; $p=0.02$ for $\mathrm{C}$ ), and one seventh of the number of individual fish $(p<0.001$ for $\mathrm{F}$ and $\mathrm{C})$, than traps placed in the seaweed farm (F) and the seagrass bed (C).

In terms of total catch weight, the pattern differed slightly; there was no difference between the sites for fish and crabs combined $\left(F_{2,17}=1.53 ; p=0.136\right)$, but a difference when comparing the weight of fish alone $\left(F_{2,17}=7.15 ; p=0.002\right)$ (Fig. 3b). As in the analyses of the no. of individuals per catch, there was no difference between the seaweed farm $(F)$ and the seagrass bed $(C)(p=0.95)$. However, traps placed in the sand bank (S) fished on average one fifth of the fish weight of traps placed in the two vegetated sites (F and C) ( $p=0.006$ compared to $\mathrm{F} ; p=0.003$ compared to $\mathrm{C}$ ).

In terms of number of species, there was also a general difference between the sites, both in terms of fish and crabs combined $\left(F_{2,17}=5.49 ; p=0.0068\right)$ and fish alone $\left(F_{2,17}=12.07\right.$; $p<0.001$ ) (Fig. 3c). There were almost two times more species of fish and crabs combined in catches from the seaweed farm $(\mathrm{F})$ than the sand bank $(\mathrm{S})(p=0.005)$, but no difference found between the sand bank and the seagrass bed ( $p=0.28$ ), or between the seaweed farm and the seagrass bed ( $p=0.18)$. Comparing only the no. of fish species, catches from the seagrass bed $(\mathrm{C})$ and the seaweed farm $(\mathrm{F})$ had three times more species than the sand bank $(\mathrm{S})(p<0.001 \mathrm{com}-$ pared to $\mathrm{F} ; p=0.005$ compared to $\mathrm{C}$ ).

Finally, in terms of mean size of fish there was no difference between any of the sites (Kruskal Wallis; $p=0.51$ ) (Fig. 3d).

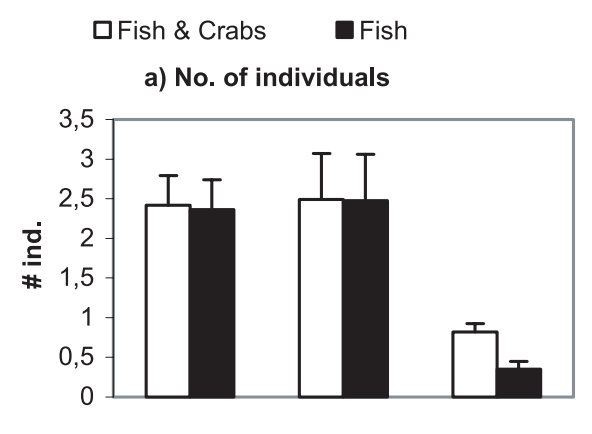

b) Catch weight

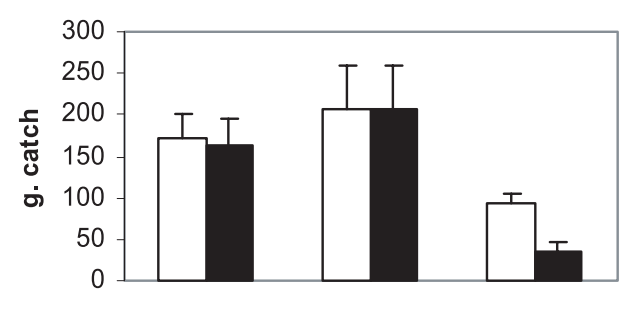

c) No. of species

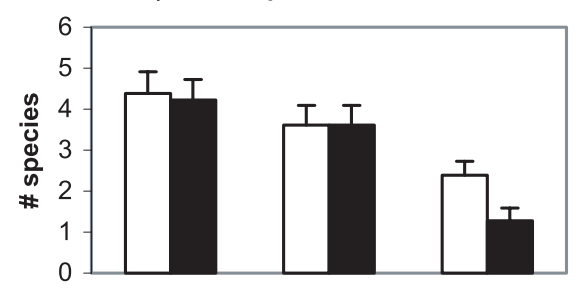

d) Mean fish size

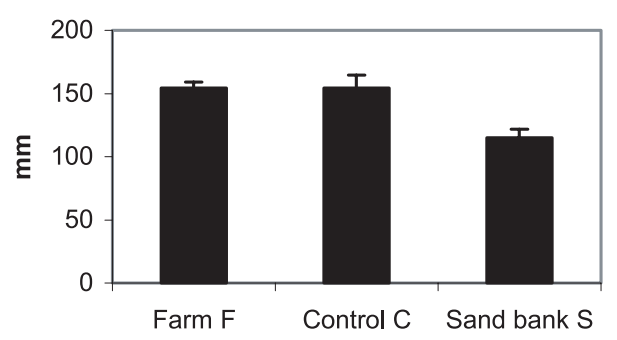

Fig. 3. a) No. of individuals, b) weight (g), c) no. of species, d) mean size of fish (SL, mm) from basket trap catches in three sites in Chwaka Bay, Zanzibar (mean $\pm \mathrm{SE} ; n=18)$.

\section{Comparisons of catch composition}

Differences between the sites in catch composition (based on weight per species and trophic groups) are displayed in Figs. $4 \mathrm{a}$ and $4 \mathrm{~b}$ (stress: 0.10 and 0.13 , respectively). Based on the weight of species, the catch composition differed between all three sites (global $R=0.61$; pairwise $R=0.48-0.76$; $p=0.001-0,002$; Fig. 4a). The three species contributing most to the differences between i) the seaweed farm $(\mathrm{F})$ and the seagrass bed (C) were Siganus sutor (13\%), Cheilinus chlorourus $(13 \%)$ and Scarus ghobban (12\%), ii) the sand bank (S) and the seaweed farm (F) Siganus sutor (17\%), Portunus pelagicus (13\%), and Leptoscarus vaigiensis (12\%) and iii) the 
Table 1. Species list, including catch weight ( $W$, in g), no. of individuals (\#) per trap and day, and mean standard length (SL, in mm), for 29 species of fish and three species of crabs caught in "madema" basket traps in three sites in Chwaka Bay, Zanzibar $(n=18)$.

\begin{tabular}{|c|c|c|c|c|c|c|c|c|c|c|c|}
\hline \multirow{2}{*}{$\begin{array}{l}\text { Site } \\
\text { Species }\end{array}$} & \multirow[b]{2}{*}{ Common name } & \multirow[b]{2}{*}{ TG } & \multicolumn{3}{|c|}{ Control C } & \multicolumn{3}{|c|}{ Seaweed farm F } & \multicolumn{3}{|c|}{ Sand bank S } \\
\hline & & & $\begin{array}{l}W \\
(\mathrm{~g})\end{array}$ & $\#$ & $\begin{array}{c}S L \\
(\mathrm{~mm})\end{array}$ & $\begin{array}{l}W \\
(\mathrm{~g})\end{array}$ & $\#$ & $\begin{array}{c}S L \\
(\mathrm{~mm})\end{array}$ & $\begin{array}{l}W \\
(\mathrm{~g})\end{array}$ & $\#$ & $\begin{array}{c}S L \\
(\mathrm{~mm})\end{array}$ \\
\hline Plotosus lineatus & Striped catfish & $\mathrm{BI}$ & 5.58 & 0.07 & 219 & 3.08 & 0.03 & 246 & - & - & - \\
\hline Papilloculiceps longiceps & Indian Ocean crocodilefish & IF & - & - & - & 3.92 & 0.01 & 378 & - & - & - \\
\hline Scorpaena scrofa & Largescaled scorpionfish & IF & 2.26 & 0.03 & 143 & - & - & - & - & - & - \\
\hline Apogon sp. & Cardinalfish & BI & 0.16 & 0.01 & 89 & - & - & - & - & - & - \\
\hline Gerres acinaces & Slenderspine mojarra & BI & 5.73 & 0.01 & 340 & - & - & - & - & - & - \\
\hline Lutjanus fulviflamma & Black-spot snapper & IF & - & - & - & 18.52 & 0.27 & 162.82 & 25.50 & 0.22 & 183 \\
\hline Lutjanus monostigma & Onespot snapper & IF & - & - & - & - & - & - & 4.48 & 0.04 & 187 \\
\hline Plectorhinchus gibbosus & Gibbus sweetlips & IF & - & - & - & 5.48 & 0.06 & 167.80 & - & - & - \\
\hline Plectorhinchus gaterinus & Blackspotted sweetlips & BI & 0.87 & 0.02 & 128 & 0.54 & 0.01 & 143 & - & - & - \\
\hline Pomadasys furcatus & Banded grunter & BI & - & - & - & - & - & - & 1.58 & 0.01 & 225 \\
\hline Lethrinus microdon & Smalltooth emperor & IF & - & - & - & 0.64 & 0.01 & 157 & - & - & - \\
\hline Lethrinus lentjan & Pink-ear emperor & I & - & - & - & 2.91 & 0.07 & 136 & - & - & - \\
\hline Lethrinus obsuletus & Orange-stripe emperor & BI & - & - & - & 0.94 & 0.01 & 133 & 0.24 & 0.01 & 112 \\
\hline Lethrinus nebulosus & Spangled emperor & I & - & - & - & 0.47 & 0.01 & 157 & - & - & - \\
\hline Parupeneus macronema & Longbarbel goatfish & BI & - & - & - & 3.16 & 0.05 & 174.50 & - & - & - \\
\hline Parupeneus indicus & Indian goatfish & BI & - & - & - & 1.66 & 0.02 & 175.50 & - & - & - \\
\hline Chaetodon melannotus & Black-backed butterflyfish & $\mathrm{O}$ & 0.19 & 0.02 & 58 & - & - & - & - & - & - \\
\hline Chaetodon auriga & Threadfin butterflyfish & $\mathrm{O}$ & 0.23 & 0.02 & 73 & 0.28 & 0.02 & 74.00 & - & - & - \\
\hline Chrysiptera annulata & Threeband demoiselle & $\mathrm{O}$ & 0.11 & 0.01 & 67 & - & - & - & - & - & - \\
\hline Cheilinus undulatus & Humphead wrasse & IF & - & - & - & - & - & - & 0.71 & 0.01 & 152 \\
\hline Cheilinus trilobatus & Tripletail wrasse & BI & 5.84 & 0.07 & 169 & 0.36 & 0.01 & 114.00 & - & - & - \\
\hline Cheilinus chlorourus & Floral wrasse & BI & 25.92 & 0.34 & 154 & - & - & - & - & - & - \\
\hline Scarus ghobban & Bluebarred parrotfish & HA & 73.90 & 0.90 & 163 & 13.50 & 0.19 & 155.14 & - & - & - \\
\hline Acanthurus xanthopteris & Yellowfin surgeonfish & H. P & - & - & - & 8.15 & 0.30 & 109.68 & 1.38 & 0.04 & 116 \\
\hline Nasinae spp. & Surgeonfish & H. P & - & - & - & 0.49 & 0.02 & 108 & - & - & - \\
\hline Siganus sutor & Seagrass rabbitfish & HA & 43.18 & 0.50 & 171 & 64.73 & 0.92 & 160.60 & - & - & - \\
\hline Siganus stellatus & Stellate rabbitfish & HA & 11.23 & 0.20 & 135 & 1.23 & 0.01 & 185 & - & - & - \\
\hline Arothron hispidus & White-spotted puffer & $\mathrm{O}$ & 2.11 & 0.01 & 182 & - & - & - & - & - & - \\
\hline Leptoscarus vaigiensis & Seagrass parrotfish & HS & 28.57 & 0.26 & 187 & 34.48 & 0.33 & 184.67 & - & - & - \\
\hline Charybdis sp. & Blue crab sp 1 & $\mathrm{O}$ & - & - & - & - & - & - & 13.83 & 0.10 & 103 \\
\hline Portunus sp. & Blue crab sp 2 & $\mathrm{O}$ & - & - & - & 5.42 & 0.04 & 120.25 & 8.76 & 0.08 & 113 \\
\hline Portunus pelagicus & Blue crab sp 3 & $\mathrm{O}$ & - & - & - & 1.72 & 0.01 & 125 & 34.62 & 0.29 & 116 \\
\hline Total \# species & & & & 15 & & & 21 & & & 9 & \\
\hline
\end{tabular}

TG: trophic group. HA: algal herbivores, HS: seagrass herbivores, H, P: herbivores and planktivores, BI: benthic invertebrate feeders, I: invertebrate feeders, IF: invertebrate and fish feeders, and O: omnivores.

a) Species

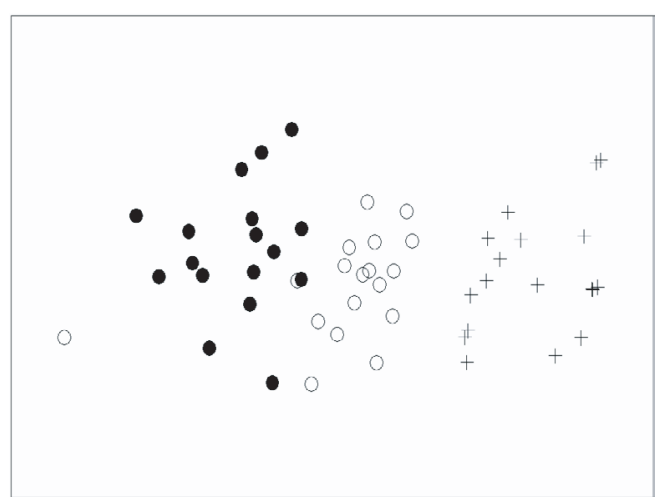

b) Trophic groups

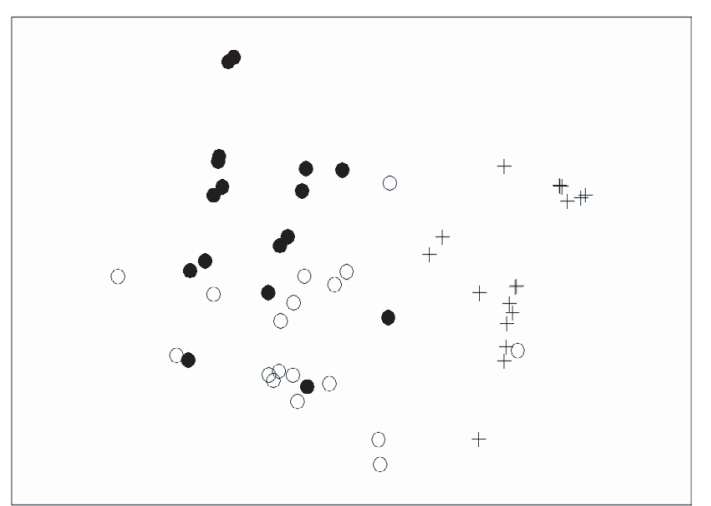

Fig. 4. Multidimensional scaling (MDS-plots) of fish trap catch composition based on catch weight; a) species, b) trophic groups from three sites in Chwaka Bay, Zanzibar $(n=18$, except for site $\mathrm{C}$ where $n=17)$. Each dot represents the daily catch averaged for five traps. Site markers are $\bullet$ : C (control seagrass); ०: F (seaweed farm); and + : S (sand bank). 
sand bank (S) and the seagrass bed (C) Cheilinus chlorourus (14\%), Scarus ghobban (13\%) and Portunus pelagicus (12\%).

Based on weights of trophic groups there was also a general difference between the sites (global $R=0.68, p=0.001$; Fig. 4b), but not as clear as in the species analysis. There was a trend to a difference in trophic group composition between the seaweed farm $(\mathrm{F})$ and the seagrass bed $(\mathrm{C})(R=0.34$; $p=0.001)$, where the trophic groups contributing to the differences were invertebrate feeders (22\%), algal herbivores (19\%) and seagrass herbivores (18\%). Further, the catch composition in the sand bank (S) was different from both that in the seaweed farm $(\mathrm{F})(R=0.75 ; p=0.001)$ and the seagrass bed $(\mathrm{C})$ $(R=0.89 ; p=0.001)$. This difference was, compared to the seaweed farm, due to algal herbivores $(25 \%)$, omnivores $(23 \%)$ and seagrass herbivores (17\%), and compared to the seagrass bed (C) due to algal herbivores (26\%), omnivores (25\%) and benthic invertebrate feeders $(23 \%)$.

In the analysis of which environmental variables that were most important for catch composition based on biomass, the results showed that a combination of tidal range and relative cover of seagrass, E. denticulatum and other macroalgae in front of the trap funnel best explained the variation in catch biomass $(\rho=0.5)$.

\subsection{Comparisons of microhabitats within a seaweed farm}

\section{Generalities}

Over the five-day study period, the water temperature was $29 \pm 0.3{ }^{\circ} \mathrm{C}$ (ranging from 28 to $30{ }^{\circ} \mathrm{C}$ ), the tidal amplitude was $1.6 \pm 0.11 \mathrm{~m}$ (ranging from 1.4 to $2.4 \mathrm{~m}$ ), and relative cloud cover was $60 \pm 14 \%$ (ranging from 5 to 95\%) (mean \pm $1 \mathrm{SE} ; n=5$ ). Hence, the conditions were comparable to those prevailing during the between-site study.

In front of traps placed close to the farmed algae, the benthic substrate was dominated by Eucheuma denticulatum $(74 \pm 3 \%)$, sand $(21 \pm 3 \%)$, seagrass $(3 \pm 1 \%)$ and other macroalgae $(2 \pm 2 \%)$, whereas the bottom in front of traps placed on sand patches was dominated by sand $(98 \pm 0.5 \%)$, seagrass $(1 \pm 0.5 \%)$ and other macroalgae $(1 \pm 0.5 \%)($ mean $\pm 1 \mathrm{SE}$; $n=5)$.

Out of the 50 traps sampled, $16(32 \%)$ were empty on retrieval, and in the remaining 34 a total of 90 individual organisms belonging to eleven species (nine fish, one crab, and one squid) were caught over the five days of sampling. Eight species were caught in traps placed close to algae, and eight in traps placed on sand patches. Five of the eleven species were caught in both treatments.

The five species contributing most to the total biomass (all traps from both treatments pooled) were seagrass rabbit fish Siganus sutor (30\%), blue crab Portunus pelagicus (20\%), white-spotted pufferfish Arothron hispidus (16\%) and bluebarred parrot fish Scarus ghobban (9\%).

\section{Microhabitat comparisons}

Traps placed close to the farmed algae caught almost two times more individual fish and crabs $(p=0.025)$ and 2.5 times more individual fish $(p=0.012)$ than traps placed on sand (Fig. 5a). Of all individuals caught in algal traps, 96\% were fish, predominantly Siganus sutor $(57 \%)$, Scarus ghobban (12\%) and Ostracion cubicus (8\%), compared to $71 \%$ for traps placed on sand, that were dominated by Portunus pelagicus (27\%), Siganus sutor (24\%) and Arothron hispidus (15\%).

In terms of total catch weight, there was no significant difference between traps placed close to algae or sand ( $p=$ $0.065)$. The main reason was probably the large contribution of and individual weight of blue crabs Portunus pelagicus, (constituting $44 \%$ of the total catch weight but only $27 \%$ of total no. of individuals) in traps placed on sand (Fig. 5b). However, in terms of fish alone, catches in traps placed close to algae caught almost three times the weight of control traps placed on sand $(p=0.016)$.

Fish constituted the major part $(94 \%)$ of the total catch weight from traps placed close to algae, predominantly Siganus sutor (40\%), Arothron hispidus (16\%), and Platycephalus indicus (11\%), while only $56 \%$ of the weight from traps placed on sand, mainly Arothron hispidus (17\%) and Siganus sutor (13\%).

Finally, there was no difference between the two treatments in the total number of species caught ( $p=0.51)$, number of fish species caught ( $p=0.11$ ) (Fig. 5c), or mean body size of fish $(p=0.23$; Fig. 5d).

\section{Discussion}

The overall results suggest that the presence of a seaweed farm, and the farmed seaweeds in particular, influences fish catches. However, since catches are from a restricted number of sites in one area over one season, the results should be seen as a starting point for future studies.

Catches in the seaweed farm (F) did not differ in terms of catch per unit effort (CPUE) i.e. no. of individuals or weight per catch, compared to the seagrass bed (C). It is possible that this was due to an overestimation of catches within the seaweed farm. First, the baited traps might offer a novel food source (seagrass leaves, epiphytic algae, sponges, etc.) that is already present in the seagrass site, and could thereby have attracted a higher proportion of the standing fish stock in the farm site than the seagrass site (and thus compensated for actual differences in fish standing stock). Second, the traps in the farm site were deliberately placed to fish the algal or remnant seagrass component of the farm complex, which could have overestimated the total CPUE for this site (given that traps placed on sand patches within farms caught three times less fish biomass; Fig. 4b). This is, however, not a major concern as sand patches only comprise a marginal portion $(<25 \%)$ of total seaweed farming areas. Instead, we believe that the results agree with a previously observed pattern - fish communities in natural algal beds differ less from seagrass beds in abundance or biomass per area than seagrass beds and unvegetated areas (for reviews see e.g. Jackson et al. 2001; Gillianders 2006), the reason being that structural complexity - provided more or less by all submerged plants - alone is considered one of the most important structuring factors for near shore fish communities (e.g. Wheeler 1980; Jenkins and Wheatley 1998). In fact, macroalgal mats in seagrass beds can sometimes, due 
$\square$ Fish \& Crabs $\quad$ Fish

a) No. of individuals

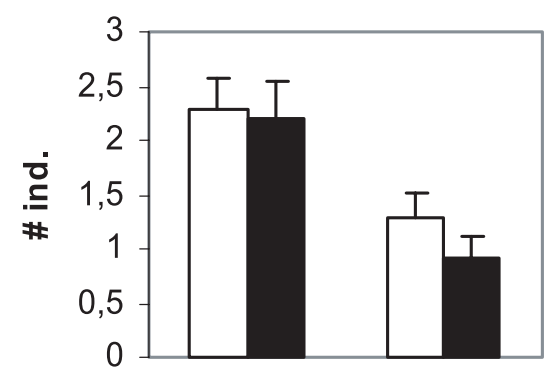

b) Catch weight

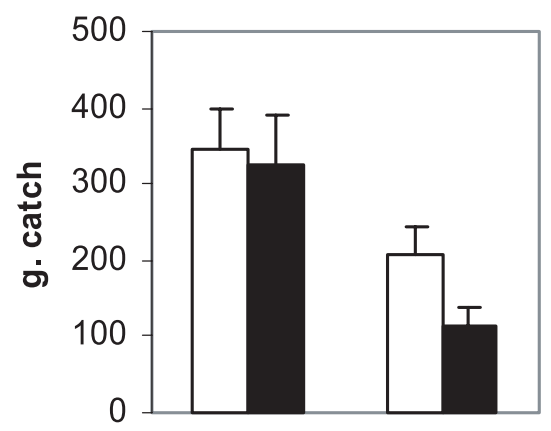

c) No. of species

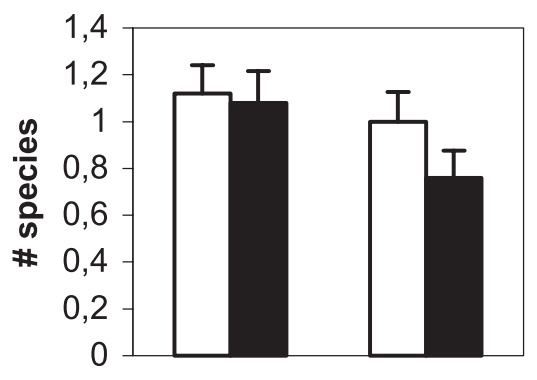

d) Mean fish size

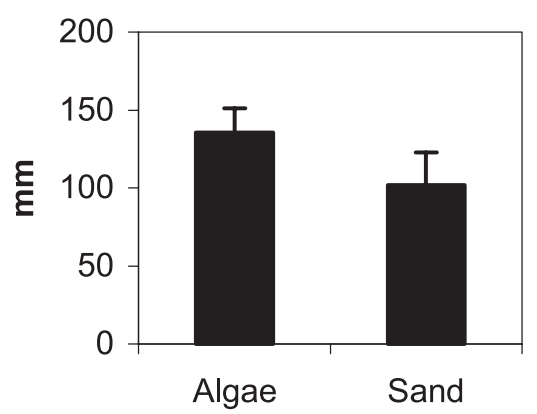

Fig. 5. a) No. of individuals, b) weight (g), c) no. of species, d) mean size of fish (SL, mm) in basket trap catches from two treatments (algae and sand) in a seaweed farm in Chwaka Bay, Zanzibar (mean \pm SE; $n=5$ ). to a higher structural complexity, provide superior predation refuge for fish, thereby increasing microhabitat abundance of fish (Adams et al. 2004). Of course seaweed farms are not directly comparable to natural algal beds; the seaweeds are suspended in the water column and not attached to the bottom substrate, there are less benthic organisms (Eklöf et al. 2005), the farms are virtual monocultures, etc. However, the clear result from the microhabitat comparison, suggests that the farmed seaweeds do indeed provide an important structural component in the habitat. Bergman et al. (2001) actually found that a seaweed farm harbored more fish per transect than a control site with $60 \%$ seagrass cover. However, the visual census technique used in that study is developed for large and highly mobile fish (Short and Coles 2001), increasing the risk of missing the small, slow-moving and cryptic species commonly encountered in seagrass beds. In that respect, we believe that "madema" traps are more useful for providing estimates of relative abundances, since they are stationary (enabling sampling in difficult habitats e.g. seaweed farms) and sample continuously for a given time period (including temporal variations in fish communities over day and night). It is however important to point out that baited traps might differ in catch efficiency due to differences in the rate at which the bait is being consumed. Further, the use of the particular bait results in a limited possibility to extrapolate the findings to the total fish community or the use of "madema" traps per se.

Compared to the sand bank (site $S$ ), catches in the seaweed farm were 3-7 times higher in terms of no. of individuals or catch weight. Even though some species, which are generally more common in the sand bank (e.g. soles) were not caught due to the specificity of the traps, the result probably reflects another general pattern - vegetation-free bottoms generally harbor lower densities of fish than vegetated ones (e.g. Ferrell and Bell 1991; Arrivillaga and Baltz 1999; Nagelkerken and van der Velde 2004). In combination with the results of the microhabitat study, this suggests that the presence of the farmed algae, even on a microhabitat scale, could constitute a determining factor in fish catches where natural vegetation is scarce. The seemingly higher catch rate in sand patches within the seaweed farm than in the sand bank (site S) used in the first study, could further indicate a "spill-over" effect from the farmed seaweeds to sand patches within the farms, similar to that demonstrated along edges of seagrass meadows (Ferrell and Bell 1991).

In terms of catch composition i.e. how much of which species were present in catches, the catches in the seaweed farm differed both from those in the sand bank and the seagrass bed. The catch composition was somewhere "in between" the two other sites (Figs. 3a-b), probably since it consisted of typical seagrass-associated species (present in catches from the seagrass bed) and sand flat species (present in catches from the sand bank) (see Table 1). This indicates that the seaweed farm could be seen as a "transition state" between a seagrass bed and a sand bank, most likely due to the presence of farmed algae, remnant seagrasses and benthic macroalgae, as well as large sand patches. However, even though all submerged plants provide structural complexity, marked differences in general traits like morphology, nutritional content, and support to associated bottom communities (e.g. meio- and macrofauna) through root 
structures, can result in differences in fish communities between seagrass meadows and algal beds (e.g. Sogard 1992; Jackson et al. 2001; Adams et al. 2004). In this study, the farmed seaweed Eucheuma denticulatum is coarsely branched, and probably a more structurally complex vegetation (in terms of the arrangement of biomass in space) than seagrasses like Enhalus acoroides and Thalassia hemprichii, and offers a concentrated food source to algal herbivores (Russell 1983; Ask et al. 2001; Neish 2003). Such differences could explain the difference in catch composition e.g. the dominance of the seagrass rabbitfish Siganus sutor in the catches from the seaweed farm (this species is well-known to associate with farmed Eucheuma seaweeds; Bergman et al. 2001; Bryceson 2002), that were observed here.

In terms of which site characteristics were important for catch composition, the combined cover of macrophytes (seagrass, benthic macroalgae and farmed algae) in front of the trap, together with the tidal range, explained $50 \%$ of the difference $(\rho=0.5)$, which supports the general theory that the actual presence of a vegetative structure is more important for fish catches than the specific type of vegetation. The impact of the tidal range is probably explained by higher catches during the middle of neap tide periods, when water levels fluctuates less and the water column is more stable compared to the start or end. However, since $50 \%$ of the variation is unexplained by the sampled variables, this suggests that i) some factors important for the catches were not included e.g. current strength or fishing activities, ii) that the dynamics of fish populations are highly variable, and iii) that there is a high element of chance involved in "madema" fisheries. The last is supported both by the fact that $43 \%$ of traps used in the first study were empty on retrieval, and that "madema" fishermen sometimes use up to ten traps simultaneously to ensure sufficient pooled catches.

A central question for the sustainability of aquaculture in general is potential environmental effects, especially regarding the impact on the flow of ecosystem goods and services to society. Even though this study seems to indicate that certain fish species are fished in comparable numbers and weights in the seaweed farms, this does not entail that seaweed farms can be compared to seagrass beds as fishing grounds providing a steady supply of fish. In Chwaka Bay, few fishermen fish in the seaweed farms, the main reason being the existence of well-established informal property right regimes and kinship relations in favor of the women seaweed farmers (de la Torre-Castro and Lindstrom, forthcoming). Furthermore, the farms are highly dynamic and heterogeneous habitats, both spatially and temporally. Fisheries are impossible to conduct during low water spring tides when farms are more or less exposed during half of the time. Furthermore, the seaweed biomass - the major provider of structural complexity - continuously changes over time by several orders of magnitude due to the repeated harvest. This entails that factors way beyond the control of farmers or fishermen e.g. season (less seaweed is farmed during rain periods) or market demand (less seaweeds are farmed when prices decrease), may influence the potential fish catches. Finally, if the farms simply aggregate fish without actually increasing fish production (e.g. by increasing survival rates within farms due to increased protection from the seaweeds), this could have implications for ecological processes involving the fish that are being attracted to the farms. For instance, Stimson et al. (2001) suggested that the normal top-down control of invasive macroalgae on Hawaiian coral reefs by fish grazing was reduced by the presence of the aquaculture algae Kappaphycus alvarezii, being the preferred food source compared to the invasive species. Such examples suggest that seaweed farming may have impacts on other ecosystems outside farms e.g. coral reefs, illustrating the complexity of biophysical interactions in the seascape biome that need to be taken into consideration.

An important final note in the context of sustainable seaweed farming is that fisheries production, although being important, is only one of the ecosystem goods and services generated by seagrass beds. Since seaweed farming seems to affect several attributes of the seagrass ecosystem, e.g. seagrass growth rates, sediment grain size and in- and epifauna communities (Eklöf et al. 2005; Eklöf et al. in press), this could entail that there are effects on other goods and services (such as efficient energy transfer and erosion control) as well. De la Torre-Castro and Ronnback (2004) describe a number of other goods (traditional medicine, fertilizers, etc.) and services (aesthetic, instrumental and spiritual values) that local communities in Chwaka Bay derive from seagrasses, and most, if not all of these, cannot be supported by seaweed farms.

Theoretically, smaller and less intense seaweed farms, or the use of other farming methods e.g. long-lines or rafts in suitable areas, may have less effect on the benthic community and the seagrass ecosystem as a whole. However, as most of the important fishing grounds are subtidal (de la Torre-Castro and Jiddawi, forthcoming), and provide higher catches than intertidal areas (Nilsson 2005), this has to be tested experimentally.

\section{Conclusion}

The presence of underwater vegetation within a seaweed farm, either seagrass or farmed algae, seems to be important for obtaining similar fish catches compared to adjacent seagrass beds within the same tidal regime. There are, however, clear differences in catch composition i.e. how much is fished of which species, which could be due to differences in vegetation structure and diversity. Furthermore, compared to an unvegetated sand bank, the presence of the farmed algae seems to increase fish catches of certain species. This could potentially be positive for fisheries production in areas without natural vegetation, if possible effects on biodiversity and ecosystem functioning first should be carefully considered. Seaweed farms are, however, a continuously changing environment due to the continuous harvesting of the algae as well as human disturbances (e.g. harvest and trampling), which in combination with natural wide-range fish dynamics makes it difficult to predict fish standing stocks and/or catches within the farms. Their suitability as fishing grounds is further complicated by various factors e.g. intertidal locality, seasonality, and institutional arrangements. Undoubtedly, increasing the understanding of the wider implications of seaweed farming, as well as other forms of aquaculture, will require multifaceted and holistic approaches, beyond the simple catch-related ecological aspects presented here. In combination with other studies showing effects of seaweed farming on other ecosystem components (e.g. 
seagrasses, meio- and macrofauna) as well as socio-economic concerns for farmers, we advocate an integrated management approach considering all components of the ecological system, including humans.

Acknowledgements. The authors wish to thank M. Andersson, M.A. Manzi and M.R. Kea for assistance in the field; Dr N.S. Jiddawi (Institute of Marine Science, UDSM, Tanzania) for logistic and scientific support; and N. Kautsky, P.-O. Moksnes, S. Sjoling, S. Wikstrom, B. Milcendeau and two anonymous referees for comments on earlier versions of this article. Financial support was provided by Sida (Swedish International Development Cooperation Agency) through a Minor Field Study scholarship to C. Nilsson and a Ph.D. research grant to M. de la Torre-Castro.

\section{References}

Adams A.J., Locascio J.V., Robbins B.D., 2004, Microhabitat use by post-settlement stage estuarine fish: evidence from relative abundance and predation among habitats. J. Exp. Mar. Biol. Ecol. 299, $17-33$

Arrivillaga A., Balz D.M., 1999, Comparison of fishes and macroinvertebrates on seagrass and bare-sand sites on Guatemala's Atlantic coast. Bull. Mar. Sci. 65, 301-319.

Ask E. I., Batibasaga A., Zertuche-Gonzalés J.A., de San, M., 2001, Three decades of Kappaphycus alvarezii (Rhodophyta) introduction to non-endemic locations. In: Chapman A.R.O., Anderson R.J., Vreeland V.J., Davison I.R (Eds.). 17th International Seaweed Symposium, Cape Town, Oxford University Press, pp. 49-57.

Bergman K.C., Svensson S., Ohman M.C., 2001, Influence of algal farming on fish assemblages. Mar. Pollut. Bull. 42, 1379-1389.

Bianchi G., 1985, FAO Species Identification Sheets for Fishery Purposes. Field guide to commercial marine and brackish water species of Tanzania. Rome, FAO.

Bryceson I., 2002, Coastal Aquaculture developments in Tanzania: Sustainable and non-sustainable experiences. W. Ind. Ocean J. Mar. Sci. 1, 1-10.

Burgess W.E., Axelrod, H.R., Hunziker III R.E., 2000, Dr. Burgess's atlas of marine aquarium fishes. Third edition. Neptune City, T.F.H. Publications.

Cederlof U., Rydberg L., Mgendi M., Mwaipopo O., 1995, Tidal exchange in a warm tropical lagoon: Chwaka Bay, Zanzibar. Ambio 24, 458-464.

Clarke K.R., 1988, Detecting change in benthic community structure. In: Proceedings of the XIVth International Biometric Conference, Namur: Invited Papers, Gemblous, Société Adophe Quélét.

Clarke K.R., 1993, Non-parametric multivariate analyses of changes in community structure. Aust. J. Ecol. 18, 117-143.

Clarke K.R., Ainsworth M., 1993, A method of linking multivariate community structure to environmental variables, Mar. Ecol. Prog. Ser. 92, 205-219.

de la Torre-Castro M., Ronnback P., 2004, Links between humans and seagrasses- an example from tropical East Africa. Ocean Coast. Manage. 47, 361-387.

Eklöf J.S., de la Torre Castro M., Adelsköld L., Jiddawi N.S., Kautsky N., 2005, Differences in macrofaunal and seagrass assemblages in seagrass beds with and without seaweed farms. Estuar. Coast. Shelf Sci. 63, 385-396.

Eklöf J.S., Henriksson R., Kautsky N., in press, Effects of tropical open-water seaweed farming on seagrass ecosystem structure and function. Mar. Ecol. Prog. Ser.
Ferrell D.J., Bell J.D., 1991, Differences among assemblages of fish associated with Zostera capricorni and bare sand over a large spatial scale. Mar. Ecol. Prog. Ser. 72, 15-24.

Froese R., Pauly. D. (Eds.), 2005, FishBase. World Wide Web electronic publication. http://www. fishbase.org (Oct. 2005).

Gell F., 1999, Fish and fisheries in the seagrass beds of Quirimba archipelago, northern Mozambique. Ph.D. Thesis, University of York.

Gell F.R., Whittington, M.W., 2002, Diversity of fishes in seagrass beds in the Quirimba archipelago, northern Mozambique. Mar. Freshw. Res. 53, 115-121.

Gillianders B.W., 2006, Seagrasses, fish and fisheries. In: Larkum A.W.D, Orth R.J., Duarte C.M. (Eds.). Seagrasses: Biology, Ecology and Conservation, Netherlands, Springer, 503-536.

Gullström M., de la Torre Castro M., Bandeira S.O., Björk M., Dahlberg M., Kautsky N., Ronnback P., Ohman M.C., 2002, Seagrass ecosystems in the Western Indian Ocean. Ambio 31, 588-596.

Gullström M., Lundén B., Bodin M., Kangwe J., Öhman M.C., Mtolera M.S.P., Björk M., 2006. Assessment of changes in the seagrass-dominated submerged vegetation of tropical Chwaka Bay (Zanzibar) using satellite remote sensing. Estuar. Coast. Shelf Sci. 67, 399-408.

Holm S., 1979, A simple sequentially rejective multiple test procedure. Scand. J. Stat. 6, 65-70.

Jackson E.L., Rowden A.A., Attrill M.J., Bossey S.J., Jones M.B., 2001, The importance of seagrass beds as a habitat for fishery species. Ocean. Mar. Biol. 39, 269-303.

Jenkins G.P., Wheatley M.J., 1998, The influence of habitat structure on near shore fish assemblages in southern Australian embayment: Comparison of shallow seagrass, reef-algal and unvegetated sand habitats, with emphasis on their importance to recruitment. J. Exp. Mar. Biol. Ecol. 221, 147-172.

Jiddawi N.S., Ohman, M.C., 2002, Marine fisheries in Tanzania. Ambio 31, 518-527.

Kangwe J. 2006, Calcareous algae of a tropical lagoon. Primary productivity, calcification and carbonate production. Ph.D. Thesis, Stockholm University.

Kaunda-Arara B., Rose G.A., 2004, Effects of marine reef national parks on fishery CPUE in coastal Kenya. Biol. Cons. 118, 1-13.

Lieske E., Myers R., 2001, Coral Reef Fishes. Indo-Pacific and Caribbean. London, HarperCollins.

McClanahan T.R., Kaunda-Arara B., 1996, Fishery recovery in a coral-reef marine park and its effect on the adjacent fishery. Cons. Biol. 10, 1187-1199.

McClanahan T.R., Mangi S., 2000, Spillover of exploitable fishes from a marine park and its effect on the adjacent fishery. Ecol. Appl. 10, 1792-1805.

McClanahan T.R., Mangi S.C., 2004, Gear-based management of a tropical artisanal fishery based on species selectivity and capture size. Fish. Manage. Ecol. 11, 51-60.

Mtolera M.S.P., Ngoile A.K., Semesi A.K., 1992, Ecological considerations in sustainable Eucheuma farming in Tanzania. In: Proc. 1 st international workshop on sustainable seaweed resources development in sub-Saharan Africa. 22-29 March 1992. Windhoek, University of Namibia, Namibia, pp. 257-263.

Muzuka A.N.N., Kangwe J.W., Nyandwi N., Wannas K.O., Mtolera M.S.P., Bjork M., 2001, Preliminary results on the sediment sources, grain size distribution and percentage cover of sandproducing Halimeda species and associated flora in Chwaka Bay. In: Richmond MD, Francis J. (Eds.), Marine science development in Tanzania and Eastern Africa. Proc. 20th ann. conference on advances in marine science in Tanzania. Zanzibar, IMS/WIOMSA, pp. 51-60. 
Nagelkerken I., van der Velde G., 2004, A comparison of fish communities of subtidal seagrass beds and sandy seabeds in 13 marine embayments of a Caribbean island, based on species, families, size distribution and functional groups. J. Sea Res. 52, 127-147.

Neish I.C., 2003, The ABC of Eucheuma Seaplant Production. http: //www. surialink. com/get/ (Oct. 2005).

Nilsson C., 2005, Comparison of catches and income for dema trap fishery in seagrass beds and seaweed farms - based on the local fishing techniques of dema fishermen. M.Sc. Thesis. Department of Systems ecology, Stockholm University.

Pollard D.A., 1984, A review of ecological studies on seagrass-fish communities, with special reference to Australia. Aquat. Bot. 18, $3-42$.

Petterson-Lofquist P., 1995, The development of open-water algae farming in Zanzibar: reflections on the socioeconomic impact. Ambio 24, 487-491.

Russell D.J., 1983, Ecology of the imported red seaweed Eucheuma striatum Schmitz on Coconut Island, Oahu, Hawaii. Pacific Sci. 37, 87-107.

Ronnback P., Bryceson I., Kautsky, N., 2002, Coastal aquaculture development in Eastern Africa and the Western Indian Ocean: prospects and problems for food security and local economies. Ambio 31, 537-542.
Semesi S., 2002, Ecological and socio-economic impacts from Eucheuma seaweeds in Zanzibar, Tanzania. M.Sc. Thesis, Noragric, Agricultural university of Norway.

Short F.T., Coles R.G., 2001, Global seagrass research methods. Amsterdam, Elsevier.

Smith M.M., Heemstra P.C., 2003, Smith's Sea Fishes. Cape Town, Struik Publishers.

Sogard S.M., 1992, Variability in growth-rates of juvenile fishes in different estuarine habitats. Mar. Ecol. Prog. Ser. 85, 35-53.

Stimson J., Larned S.T., Conklin E., 2001, Effects of herbivory, nutrient levels, and introduced algae on the distribution and abundance of the invasive macroalga Dictyosphaeria cavernosa in Kaneohe Bay, Hawaii. Coral Reefs 19, 343-357.

Warwick R.M., Clarke K.R., Suharsono, 1990, A statistical analysis of coral community responses to the 1982-1983 El Nino in the Thousand Island. Coral Reefs 8, 171-179.

Wheeler A., 1980, Fish-algal relations in temperate waters. In: Price J.H., Irvine D.E.G., Farnham W.F. (Eds.). The shore environment: Vol. 2: Ecosystems. London, Academic Press, pp. 677-698.

Zemke-White W.L., 2003, Assessment of the current knowledge on the environmental impacts of seaweed farming in the tropics. In: Proc. Asia-Pacific Conference on Marine Science and Technology, 12-16 May 2002, Kuala Lumpor, Malaysia. 